\title{
Merger Announcement Effects and the Amendment of Insider Trading Laws in Brazil
}

\author{
Mei Qiu, Sonia Aparecida Balbinotti \\ Massey University, Auckland, New Zealand
}

\begin{abstract}
Although Brazil has a long history of having insider trading laws (IT laws) in place and became the first emerging country to enforce the IT laws (Bhattacharya \& Daouk, 2002), criminal sanctions and hefty monetary penalties were only made possible by the amendment of its laws against IT on October 31, 2001. We study the stock price effects of merger announcements made by 151 firms over two periods, before and after the change of IT laws. Our empirical results suggest that target firms attained positive price run-ups in pre-announcement windows before, but not after, the legal regime change. While acquiring firms had strong positive pre-announcement reactions in both legal regimes, the abnormal returns (AR) decreased in the more stringent legal regime. These results indicate that more stringent IT laws may deter IT and improve market efficiency in an emerging country.
\end{abstract}

Keywords: merger, abnormal return (AR), event study, insider trading law (IT law)

\section{Introduction}

Merger is a major corporate event with profound valuation effect. Average gains to target firm shareholders amount to 9\% in Europe (Goergen \& Renneboog, 2004) and 20\% in the US (Boone \& Mulherin, 2007). Shareholders of bidding firms, however, realise smaller gains (Asquith, Bruner, \& Mullins, 1983) and losses (Billett \& Qian, 2008; Doeswijk \& Hemmes, 2001; Morck, Shleifer, \& Vishny, 1990; Mulherin \& Boone, 2000). Furthermore, substantial pre-announcement price run-ups often occur in target firm stocks and sometimes in acquiring firm stocks due to insider trading (IT) or market speculation (Aitken \& Czernkowski, 1992; Keown \& Pinkerton, 1981; Meulbroek, 1992; Meulbroek \& Hart, 1997; Schwert, 1996). Banerjee and Eckard (2001) claimed that insiders captured all merger gains prior to public announcements in the first merger wave of 1897-1903.

IT is a misappropriation of private information that is unfair to the general public (Cao, Field, \& Hanka, 2004; Chakravarty \& McConnell, 1999; Jeng, Metrick, \& Zeckhauser, 2003). Stock markets are more volatile (Du \& Wei, 2004) and the costs of capital are higher in countries where IT prevails. To ensure market integrity, many countries have established laws against IT (IT laws) (Doffou, 2003; Rozeff, 1989), although the form and severity of the penalties for offenders vary substantially. Bris (2005) reported that the incidence of offense is lower in countries with more stringent IT laws. After initial law enforcement, some countries raised the penalties for offenders in an effort to deter IT. Beny (2005) showed that the stock markets are more efficient in

Mei Qiu, senior lecturer, School of Economics and Finance (Albany), Massey University (Albany). Email: M.Qiu@massey.ac.nz.

Sonia Aparecida Balbinotti, postgraduate student, School of Economics and Finance (Albany), Massey University (Albany). 
countries with hefty monetary penalties and criminal sanctions. Although the IT laws in many countries have been amended to increase the level of penalties for offenders, academic studies on the effectiveness of these changes are limited and the results are inconclusive. Garfinkel (1997) and Min (2010) found that IT in the United States reduced substantially after the IT laws were tightened in the 1980s. On the contrary, Khan and Lamba (2001) and Seyhun (1992) argued that monetary penalties and criminal sanctions do not have deterrent effects on IT. In New Zealand, an enactment of stricter IT laws in 2002 improved the stock market efficiency (Frijns, Gilbert, \& Tourani-Rad, 2008) while the imposition of criminal sanctions in 2008 had little impact on IT (Frijns, Gilbert, \& Tourani-Rad, 2013). In the Netherlands, price run-ups prior to merger announcements decreased after the financial penalties for IT were increased in 2005 (Prevoo \& Weel, 2010).

The finance literature, however, provides no empirical evidence on the effects of adopting stricter IT laws in an emerging market. In this paper, we intend to fill this gap by conducting a comparative study of merger announcements made in Brazil over two time periods divided by the enactment of more stringent IT laws on October 31, 2001. We believe that Brazil is an interesting country for a study for several reasons. First, Brazil has a long history of IT law enforcement as it is the first emerging country to enforce IT laws (Bhattacharya \& Daouk, 2002). ${ }^{1}$ More interestingly, despite having a broad scope of IT laws, expectations of criminal or monetary sanctions have been extremely low in Brazil for several decades (Beny, 2005). ${ }^{2}$ On October 31, 2001, the Securities and Exchange Commission of Brazil (CVM) amended the IT laws to by passing Article 27-D of Law 10.303 in the Corporate Act to make criminal offense and punishment by imprisonment of inside traders possible. To better discipline the capital markets, the amendment in 2001 also increased the limit of pecuniary penalties to three times that of the profits from IT. On January 3, 2002, the CVM released Instruction 358 to regulate the disclosure and use of information about the material events of public firms which requires that "mergers and changes in corporate control are material events that may have a significant influence on security prices and decisions made by the market participants". After a change to more stringent IT laws in 2001, expectations of sanctions in Brazil became the highest among emerging countries. ${ }^{3}$

In addition, the Brazilian stock market experienced rapid growth following its adoption of electronic trading systems in the 1990s. The stock exchange of Brazil, BM\&FBOVESPA, became the 10th biggest stock exchange in the world in terms of total market capitalisation at the end of 2009. ${ }^{4}$ In a country where corruption is culturally acceptable (De Medeiros, 2009), impending merger deals are often poorly held secrets and insider dealings are frequent and profitable (Rochman \& Eid, 2006). In the takeover of Ipiranga Group in 2007, for example, the firm's stock price increased by $56 \%$ in the five days leading up to the official merger announcement. The president of CVM commented that "unexplained movements in shares and options, or leaks in newspapers occur before almost every M\&A deal” (Marotto \& Winterstein, 2007, p. 1). The regime change of IT laws in 2001 and the existence of an active takeover market make Brazil an ideal market for conducting a comparative study of abnormal market reactions to merger announcements in two different regimes of IT laws.

\footnotetext{
${ }^{1}$ Brazil established IT laws in 1976 and became the third country in the developing world to do so. The first prosecution of insider dealing took place in 1978.

${ }^{2}$ Beny (2005) measured the scope and sanctions of a country's IT laws on a scale of 0-2, where a score of 2 indicates the most restrictive laws. Based on the IT laws of Brazil in 1994, Beny assigned Brazil a score of 2 for scope and 0 for sanctions.

${ }^{3}$ We update the scope and sanction scores for Brazil's IT laws after the legal amendment of 2001. Based on these measures as defined by Beny (2005), we assign Brazil a new score of 2 for sanctions. The score for scope remains unchanged, at the highest value of 2, from 2001 on.

4 See the Annual Statistics Reports, retrieved from the website of the World Federation of Exchanges at http://www.world-exchanges.org/statistics/annual/2009.
} 
The rest of the paper is organized as follows. Section 2 provides a description of data and methodology. Section 3 presents the empirical findings of studies based on the full sample and the sub-samples observed in two different IT law regimes. The last section concludes with a summary of the main research findings.

\section{Data and Methodology}

The sample for this study includes 26 target firms and 125 acquiring firms in merger announcements made between January 1995 and January 2010. We begin sampling in 1995 for two reasons. First, merger activities in South American countries grew exponentially in the 1990s but were negligible in the 1980s (Gaughan, 2011). Second, trading in Brazilian stock markets only became active after the adoption of electronic trading systems in the mid-1990s. The sample ends at the end of 2009, when the takeover market slowed down in the midst of the latest global financial crisis.

Announcements of mergers are retrieved from Factiva. For a same deal that has consecutive announcements within one month, we include only the first one to avoid the compounding effects of earlier announcements. Firms that made earnings, dividend, or other significant corporate announcements over the event window are excluded. We also exclude firms not listed on Brazil's stock exchange, firms with fewer than 60 days of observable stock prices over the estimation period of the event study, and thinly traded stocks with more than 30 days of stagnant stock prices in a 61-day event window. For mergers that do not explicitly state the acquiring firms, we identify the acquirers and targets by examining the characteristics of the merged firms (such as which firm's name is retained and which management team remained in charge after the merger). For each full sample of target and acquiring firms, we create two sub-samples of observations taken from the two periods, one before and one after the enactment of stricter IT laws on October 31, 2001. A summary of the sample compositions is presented in Table 1. A detailed list of firms in the samples is omitted but available upon request from the corresponding author. The acquirers make up a greater part of the entire sample because many target companies were either not listed or newly listed at the time the mergers and acquisitions were announced. Due to the small sample size of target firms, we do not differentiate between domestic and cross-border mergers.

Table 1

Samples Before and After the Change in IT Laws

\begin{tabular}{lccc}
\hline & Pre-change period & Post-change period & Full period \\
\hline Target & 8 & 18 & 26 \\
Acquirer & 23 & 102 & 125 \\
Target and acquirer & 31 & 120 & 151 \\
\hline
\end{tabular}

We conduct a standard event study to estimate the abnormal returns (AR) of individual firms in the sample using the market model in Equation (1), where the characteristics ( $\alpha$ and $\beta$ ) of individual stocks are estimated from the data observed over a 140-day estimation period that ends 31 days before the merger announcement. The estimates of stock characteristics are then used as inputs for Equation (2) to calculate the required rates of returns $(\hat{R})$ of individual stocks on day $t$ in a 61-day event period beginning 30 days before the merger announcement. Next, we use Equations (3) and (4) to calculate the ARs and the cumulative abnormal returns (CAR), on an event day $t$ or over an event window $T$, respectively: 


$$
\begin{gathered}
R_{i, t}=\alpha_{i}+\beta_{i} \times R_{m, t} \\
\hat{R}_{i, t}=\alpha_{i}+\beta_{i} \times R_{m, t} \\
A R_{i, t}=R_{i, t}-\hat{R}_{i, t} \\
C A R_{i, T}=\sum_{t=T_{1}}^{T_{2}} A R_{i, t}
\end{gathered}
$$

where $R_{i}$ is the return of stock $i, R_{m, t}$ is the return of the market index using the Ibovespa index as a proxy; subscript $t$ indicates the day of the observation and $T_{1}$ and $T_{2}$ denote the starting and ending dates, respectively, of the event window $T$.

We obtain the statistical significance of AR and CAR from the two-tailed Patell tests with a null hypothesis of a zero mean. In addition, we use the non-parametric generalised sign test to obtain additional information about the distribution of signs of the AR and CAR. We retrieve the daily total return index (RI) for the Ibovespa index and individual stocks from Datastream. The results of our empirical analysis are presented in the following two sections.

\section{Empirical Results}

\section{Results for Full Sample Period}

Table 2 reports the average AR to target and acquiring firms for selected event days and windows. To keep the discussion succinct, insignificant results obtained for other days and windows are omitted but available upon request from the authors. Figures in Panel A show that target firms realised significant positive ARs on the day before (averaged at 2.57\%) and the day of (averaged at 3.89\%) official merger announcements, both statistically significant at the $1 \%$ level. In the post-announcement period, target firms experienced significant price reversals on day 11 (averaged at $-1.65 \%$ ) and day 15 (averaged at $-1.18 \%$ ). A statistically significant average CAR of $6.90 \%$ is observed from a three-day event window $(-1,1)$. We also report weak evidence of positive (negative) CARs in the pre-announcement (post-announcement) windows which do not have statistical significance. Referring to Panel B, acquiring firms attained positive average ARs 17, nine, five, and four days before the announcement day. The average daily AR varies between $0.40 \%$ and $0.51 \%$, with statistical significance at the $10 \%$ level or above. This positive sentiment continued to accrue on the announcement day (with an AR of $0.77 \%$ ) and the day after the announcement day (with an AR of $0.85 \%$ ), both statistically significant at the $1 \%$ level. Statistically significant price reversals appeared eight days $(-0.21 \%)$ and 18 days $(-0.44 \%)$ after the announcements. The CARs of the acquiring firms are $3.11 \%, 1.76 \%$, and $1.49 \%$ in the pre-announcement windows $(-30,-1),(-20,-1)$, and $(-10,-1)$, respectively, with statistical significance at the $5 \%$ level or above. Furthermore, an average CAR of $0.93 \%$ is observed from the five-day post-announcement window $(1,5)$, with statistical significance at the $5 \%$ level. We also find weak price reversals in longer post-announcement windows with no statistical significance.

For the entire sample period from January 1995 to December 2009, we report the average AR and the average CAR to the target and acquiring firms on selected days and windows that have statistically significant test results. Day 0 (event day) is defined as the day a merger is first announced. 
Table 2

AR Over the Full Period of Study

\begin{tabular}{|c|c|c|c|c|c|}
\hline \multicolumn{6}{|c|}{ Panel A: Target firms $(n=26)$} \\
\hline Date & $\mathrm{AR}$ & Pos:Neg & Window & CAR & Pos:Neg \\
\hline-9 & $0.54 \%$ & $15: 11$ & $(-30,-1)$ & $-0.62 \%$ & $10: 16$ \\
\hline-5 & $0.51 \%$ & $12: 14$ & $(-20,-1)$ & $-0.27 \%$ & $12: 14$ \\
\hline-1 & $2.57 \%^{* * *}$ & $17: 9^{*}$ & $(-10,-1)$ & $2.87 \%$ & $14: 12$ \\
\hline 0 & $3.89 \%{ }^{* * *}$ & $14: 12$ & $(-1,1)$ & $6.90 \%{ }^{* * *}$ & $19: 7^{* * *}$ \\
\hline+1 & $0.44 \%$ & $13: 13$ & $(1,5)$ & $-1.19 \%$ & 9:17 \\
\hline+11 & $-1.65 \%{ }^{* * *}$ & 9:17 & $(1,20)$ & $-5.30 \%$ & $13: 13$ \\
\hline+15 & $-1.18 \%{ }^{* *}$ & 9:17 & $(1,30)$ & $-5.62 \%$ & $13: 13$ \\
\hline \multicolumn{6}{|c|}{ Panel B: Acquiring firms $(n=125)$} \\
\hline Window & AR & Pos:Neg & Window & CAR & Pos:Neg \\
\hline-17 & $0.51 \%^{* *}$ & $70: 55^{* *}$ & $(-30,-1)$ & $3.11 \%^{* *}$ & $77: 48^{* * *}$ \\
\hline-9 & $0.46 \%{ }^{*}$ & $74: 51^{* * * *}$ & $(-20,-1)$ & $1.76 \%{ }^{* *}$ & $67: 58$ \\
\hline-5 & $0.50 \%^{* * *}$ & $51: 74$ & $(-10,-1)$ & $1.49 \%{ }^{* *}$ & $69: 56^{*}$ \\
\hline 0 & $0.77 \%^{* * *}$ & $70: 55^{* * *}$ & $(-1,1)$ & $0.23 \%$ & $65: 60$ \\
\hline+1 & $0.85 \%{ }^{* * *}$ & 63:62 & $(1,5)$ & $0.93 \%{ }^{* *}$ & $65: 60$ \\
\hline+8 & $-0.21 \%^{*}$ & $53: 72$ & $(1,20)$ & $-0.31 \%$ & $56: 69$ \\
\hline+18 & $-0.44 \%^{* *}$ & $48: 77$ & $(1,30)$ & $-0.40 \%$ & $58: 67$ \\
\hline
\end{tabular}

Note. The superscripts ", , and ${ }^{*}$ denote the statistical significance of the Patell or generalised sign tests at the $10 \%, 5 \%$, and $1 \%$ levels, respectively.

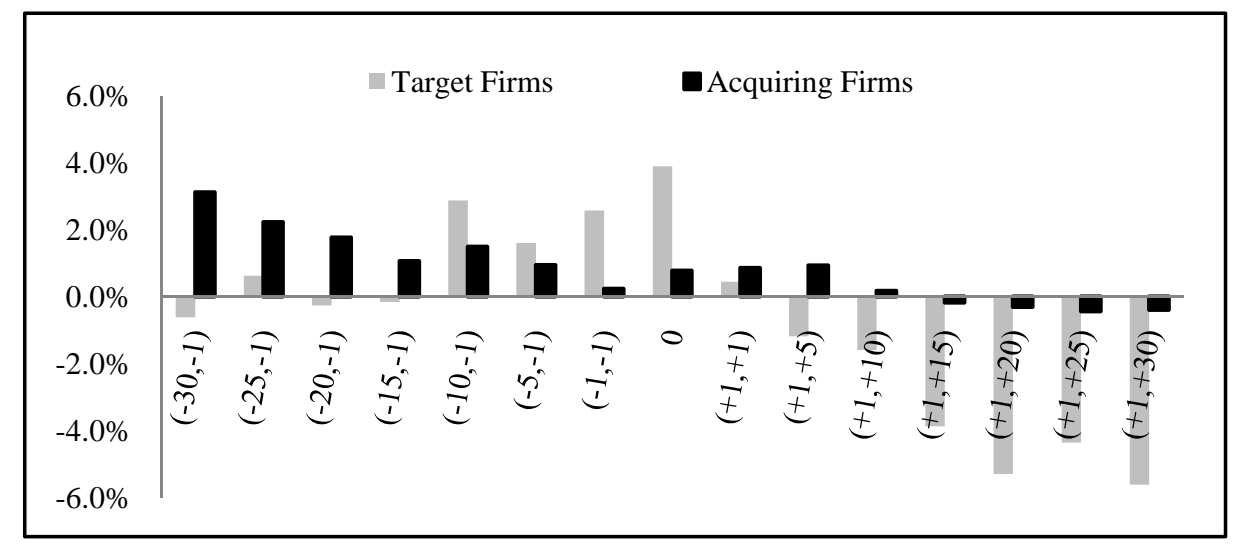

Figure 1. Average CAR over the full sample period.

The contrast between the target and acquiring firms' performance is illustrated more intuitively in Figure 1. While both groups exhibit positive pre-announcement effects, the CAR of acquiring firms peaked in the window $(-30,-1)$, while target firms peaked in the window $(-10,-1)$. Target firms displayed stronger positive reactions than acquiring firms on the day before and the day of the announcement. In the post-announcement period, both target and acquiring firms experienced price reversals, although the magnitude of reversals is substantially higher for target firms. The empirical results of this study are generally consistent with the findings of Alexandridis, Petmezas, and Travlos (2010), Asquith et al. (1983), and Keown and Pinkerton (1981). However, the lack of statistical significance in both the pre- and post-announcement CARs of target firms contradicts the general findings of the literature. Therefore, further investigation needs to be done to reconcile our results with the literature. 


\section{Results for Sub-sample Periods Before and After the Amendment of IT Laws}

Table 3 presents the AR and CAR to target and acquiring firms during the two periods before and after the amendments of IT laws in 2001. The results in Panel A suggest that daily AR of target firms peaked one day after the announcement day prior to the change in IT laws, but peaked on the announcement day after the change in IT laws. Target firms realised statistically significant average positive ARs in the lax legal regime 25 days (2.75\%), 24 days (3.32\%), and three days (2.10\%); and in the harsher legal regime 21 days (1.42\%), 20 days (1.43\%), and one day (2.97\%) before the announcement day. In the lax law environment, statistically significant positive ARs accumulated over the pre-announcement windows $(-15,-1),(-10,-1)$, and $(-5,-1)$; averaged at $7.99 \%, 9.87 \%$, and $6.34 \%$, respectively. The announcement day effect is negative but weak, while a significant positive AR of $4.51 \%$ is observed for the day after the announcement day. These results are contradictory to our findings for the full sample but consistent with the general findings of the literature. In the more stringent legal environment, however, the announcement day average AR is $6.36 \%$, with a statistical significance of $1 \%$. In the post-announcement windows, target firms had weak negative CAR in the lax legal regime but experienced significant price reversals of $-1.79 \%$ and $-1.70 \% 11$ days and 15 days, respectively, after the announcement day. We also find a significant cumulative price reversal of $-6.60 \%$ for the post-announcement window $(1,20)$ in the harsher legal regime for target firms.

Table 3

AR Before and After the Change in IT Laws

\begin{tabular}{|c|c|c|c|c|c|c|}
\hline \multicolumn{7}{|c|}{ Panel A: Target firms } \\
\hline \multicolumn{2}{|c|}{ Before change $(n=8)$} & \multicolumn{2}{|c|}{ After change $(n=18)$} & \multirow{2}{*}{ Window } & \multirow{2}{*}{$\begin{array}{l}\text { Before }(n=8) \\
\text { CAR }\end{array}$} & \multirow{2}{*}{$\begin{array}{l}\text { After }(n=18) \\
\text { CAR }\end{array}$} \\
\hline Day & AR & Day & AR & & & \\
\hline-25 & $2.75 \%^{* *}$ & -21 & $1.42 \%^{* *}$ & $(-20,-1)$ & $4.82 \%$ & $-2.53 \%$ \\
\hline-24 & $3.32 \%{ }^{* * *}$ & -20 & $1.43 \%{ }^{* * *}$ & $(-15,-1)$ & $7.99 \%{ }^{*}$ & $-3.79 \%{ }^{* *}$ \\
\hline-5 & $1.85 \%{ }^{*}$ & -1 & $2.97 \%{ }^{* * *}$ & $(-10,-1)$ & $9.87 \%{ }^{* * *}$ & $-0.24 \%$ \\
\hline-3 & $2.10 \%{ }^{*}$ & 0 & $6.36 \%{ }^{* * *}$ & $(-5,-1)$ & $6.34 \%{ }^{* *}$ & $-0.51 \%$ \\
\hline 0 & $-1.67 \%$ & +4 & $1.28 \%{ }^{*}$ & $(-1,1)$ & $4.50 \%^{* *}$ & $7.96 \%$ \\
\hline+1 & $4.51 \%^{* * *}$ & +11 & $-1.79 \%{ }^{* * *}$ & $(1,5)$ & $-1.56 \%$ & $-1.03 \%$ \\
\hline+20 & $-1.12 \%$ & +15 & $-1.70 \%^{* * *}$ & $(1,20)$ & $-2.38 \%$ & $-6.60 \%^{*}$ \\
\hline \multicolumn{7}{|c|}{ Panel B: Acquiring firms } \\
\hline \multicolumn{2}{|c|}{ Before change $(n=23)$} & \multicolumn{2}{|c|}{ After change $(n=102)$} & \multirow{2}{*}{ Window } & Before $(n=23)$ & After $(n=102)$ \\
\hline Day & AR & Day & AR & & CAR & CAR \\
\hline-17 & $1.27 \%^{* *}$ & -17 & $0.34 \%^{*}$ & $(-30,-1)$ & $3.96 \%{ }^{*}$ & $2.92 \%{ }^{*}$ \\
\hline-9 & $1.31 \%^{* * *}$ & -9 & $0.27 \%$ & $(-20,-1)$ & $3.34 \%{ }^{*}$ & $1.40 \%$ \\
\hline-5 & $0.56 \%{ }^{* * *}$ & -4 & $0.37 \%^{* *}$ & $(-10,-1)$ & $2.74 \%{ }^{* *}$ & $1.21 \%$ \\
\hline-1 & $0.77 \%{ }^{*}$ & 0 & $0.73 \%{ }^{* *}$ & $(-5,-1)$ & $0.42 \%$ & $1.06 \%{ }^{* *}$ \\
\hline 0 & $0.94 \%{ }^{* *}$ & +1 & $0.67 \%^{* *}$ & $(-1,1)$ & $3.39 \%{ }^{* * *}$ & $1.50 \%{ }^{* * *}$ \\
\hline+1 & $1.68 \%{ }^{* * *}$ & +5 & $-0.21 \%$ & $(1,5)$ & $0.95 \%{ }^{* *}$ & $0.93 \%$ \\
\hline+13 & $-1.53 \%{ }^{* *}$ & +18 & $-0.39 \%{ }^{* *}$ & $(1,30)$ & $1.31 \%$ & $-0.78 \%$ \\
\hline
\end{tabular}

Note. The superscripts ${ }^{* * *}$, and ${ }^{* * * *}$ denote the statistical significance of the Patell test at the $10 \%, 5 \%$, and $1 \%$ levels, respectively.

We divide each sample of the target and acquiring firms into two groups, one before and one after the enactment of IT laws on October 31, 2001. For each subgroup of the target and acquiring firms, we report the average AR and the average CAR on selected days and windows that have statistically significant test results. Day 0 (event day) is defined as the day a merger is first announced. 
Figure 2 presents a more intuitive picture of the comparison between the abnormal performances of target firms under two different law regimes. The most striking difference is the significant positive effect in the lax law regime versus the weak negative effects in the strict law regime in the pre-announcement period, indicating improved efficiency in the stock market after the enactment of stricter IT laws. While price reversals succeeding the announcements are observed in both regimes, the reversals became stronger after the regime change in IT laws. Comparing the abnormal performance of target firms during the two IT law regimes, we find substantial variations in the patterns and signs of AR before, on, and after the merger announcements. The abnormal and cumulative returns changed dramatically, in terms of both size and timing, after the enactment of more stringent IT laws in 2001. Considering that our target firm sample is relatively small, it is not surprising that the significant pre-announcement price run-ups of target firms established in the merger literature are not supported by our results.

The results in Panel B of Table 3 show that the stocks of acquiring firms attained statistically significant positive AR from 17 days before until one day after the announcement day in the lax legal regime. The highest daily AR was $1.68 \%$, realised on the day after the announcements. The average CAR in the pre-announcement window $(-30,-1)$ was $3.96 \%$ with a statistical significance at the $10 \%$ level. While a significant price reversal of $-1.53 \%$ is observed on the 13th day after the announcements, we find no evidence of significant price reversals in any post-announcement windows in the lax law regime. We find that AR of acquiring firms decreased substantially after the enactment of harsher IT laws. The highest daily AR is observed on the announcement day, averaged at $0.73 \%$ as compared to a $0.94 \%$ in the lax legal regime. An average CAR of $2.92 \%$ is observed in the pre-announcement window $(-30,-1)$, approximately $1 \%$ lower than the level it was in the lax legal regime.

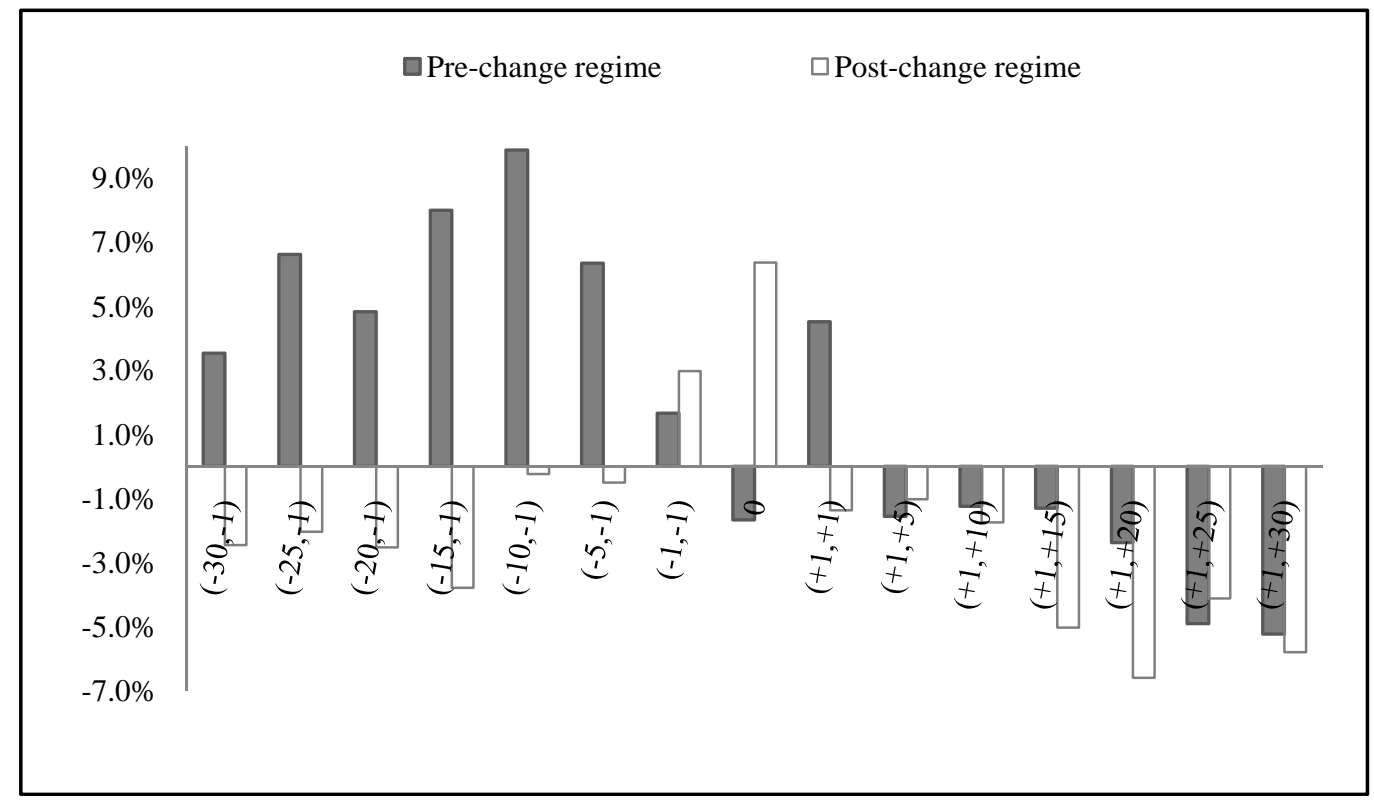

Figure 2. Average CAR of target firms. 


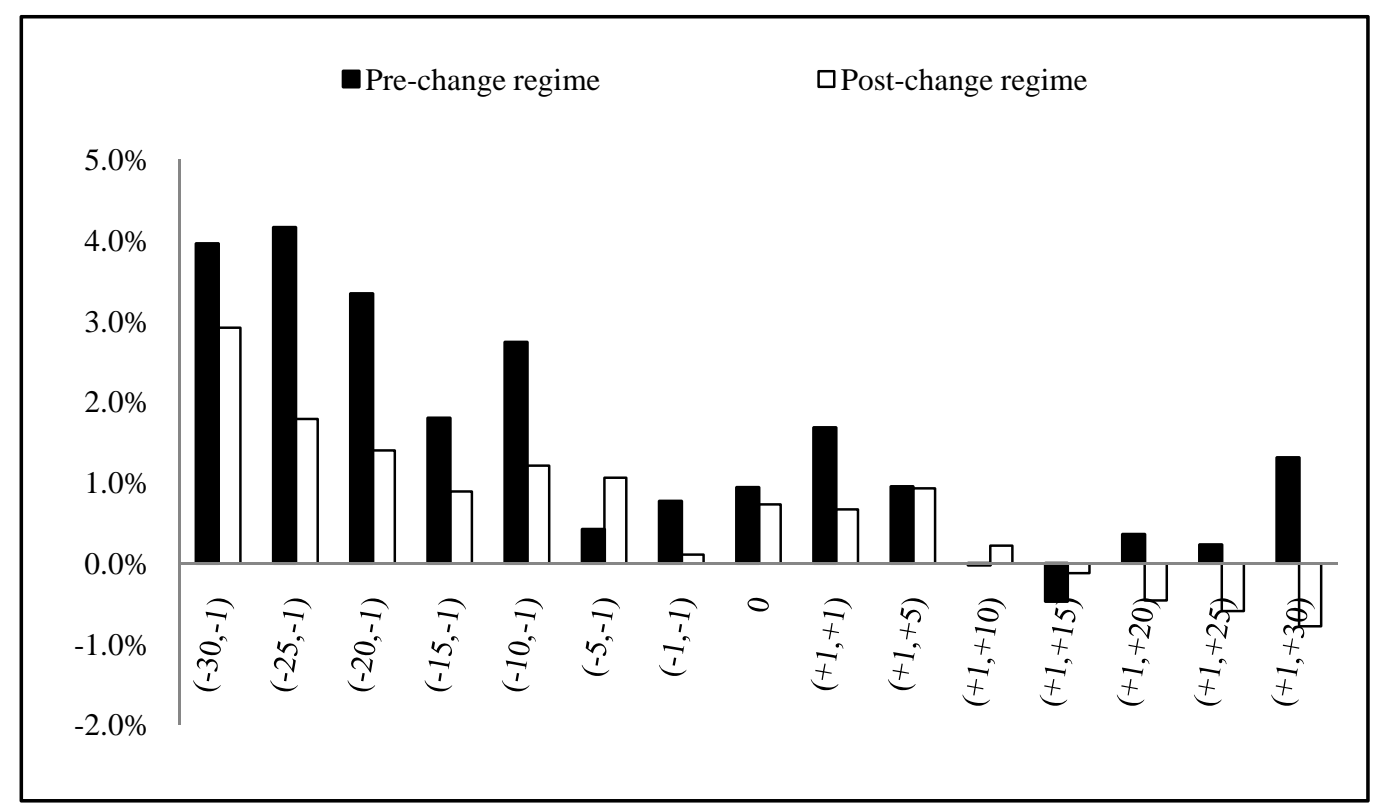

Figure 3. Average CAR of acquiring firms.

Figure 3 provides a more intuitive picture of the comparison between the abnormal performances of acquiring firms in the different IT law environments. The plots show that acquiring firms attained significant pre-announcement price run-ups in both periods of study. In addition, significant positive ARs are reported for acquiring firms on the announcement day and the day after the announcement day in both regimes of study; although these results became weaker after the regime change. Furthermore, a statistically significant positive CAR of $0.95 \%$ is observed for the post-announcement window $(1,5)$ for the pre-change regime. While acquiring firms displayed some post-announcement price reversals in both regimes, the reversal effect decreased after the law amendment of 2001. Consistent with the findings for target firms in the two IT law regimes, the results for acquiring firms suggest that IT profits decreased substantially after the enactment of more stringent IT laws.

\section{Conclusions}

We study the merger announcement effects of 151 Brazilian firms and find that pre-announcement window price run-ups are statistically significant for acquiring firms but not for target firms, contradicting the general findings in the literature. A further investigation reveals that the enactment of harsher IT laws in October 2001 had significant impact on the AR of target firms. By comparing the merger announcement effects in two different legal regimes, we find that shareholders of target firms attained statistically significant AR on the announcement day in the more stringent, but not lax, legal regime. We also find that target firm stocks realised significant positive CAR in pre-announcement windows in the lax, but not more stringent, legal regime. After the enactment of harsher laws, pre-announcement price run-ups decreased but announcement day AR increased in target firms. The shareholders of acquiring firms, on the other hand, realised significant gains before and on the announcement day in both legal regimes. AR on the announcement day and CAR in the pre- and post-announcement periods, however, decreased after the enactment of harsher laws. 
The reduced pre-announcement price run-ups and ARs of target and acquiring firms in the harsher IT law environment suggest reduced IT activity and improved stock market efficiency in Brazil since the law amendment of 2001, consistent with the conclusions of Frijns et al. (2008), Garfinkel (1997), Min (2010), and Prevoo and Weel (2010) in studies of developed markets. Our finding has important policy implications for other emerging markets that have not yet imposed severe penalties for the offenses of IT, and practical implications for practitioners. Although the magnitudes of significant pre-announcement price run-ups of target and acquiring firms were large enough for insiders to make profitable trades after the deduction of transaction costs in the lax law regime, this profitable opportunity remains only in trading the stocks of acquiring firms since the law amendment of 2001.

One must be cautious, however, in the interpretation and generalisation of the results we draw from a small sample of target firms. In addition, the reduction in the pre-announcement price run-ups of the sample firms after the law amendments could be the result of an overall improvement in market efficiency driven by other factors. Future studies may explore this topic further using the data of other emerging markets or examining other types of corporate events.

\section{References}

Aitken, M., \& Czernkowski, R. (1992). Information leakage prior to takeover announcements: The effect of media reports. Accounting and Business Research, 23(89), 3-20.

Alexandridis, G., Petmezas, D., \& Travlos, N. G. (2010). Gains from mergers and acquisitions around the world: New evidence. Financial Management, 39(4), 1671-1695.

Asquith, P., Bruner, R. F., \& Mullins, D. W. (1983). The gains to bidding firms from merger. Journal of Financial Economics, 11(1-4), 121-139.

Banerjee, A., \& Eckard, E. W. (2001). Why regulate insider trading? Evidence from the first great merger wave (1897-1903). American Economic Review, 91(5), 1329-1349.

Beny, L. N. (2005). Do insider trading laws matter? Some preliminary comparative evidence. American Law and Economics Review, 7(1), 144-183.

Bhattacharya, U., \& Daouk, H. (2002). The world price of insider trading. Journal of Finance, 57(1), 75-108.

Billett, M. T., \& Qian, Y. (2008). Are overconfident CEOs born or made? Evidence of self-attribution bias from frequent acquirers. Management Science, 54(6), 1037-1051.

Boone, A. L., \& Mulherin, J. H. (2007). How are firms sold? The Journal of Finance, 62(2), 847-875.

Bris, A. (2005). Do insider trading laws work? European Financial Management, 11(3), 267-312.

Cao, C., Field, L. C., \& Hanka, G. (2004). Does insider trading impair market liquidity? Evidence from IPO lockup expirations. Journal of Financial and Quantitative Analysis, 39(1), 25-46.

Chakravarty, S., \& McConnell, J. J. (1999). Does insider trading really move stock prices? Journal of Financial and Quantitative Analysis, 34(2), 191-209.

De Medeiros, O. R. (2009). Insider trading in the Brazilian stock market. SSRN Working Paper. Retrieved from http://papers.ssrn.com/sol3/papers.cfm?abstract_id=1457444

Doeswijk, R., \& Hemmes, H. S. K. (2001). Mergers and acquisitions in a global context: Reaction of price and earnings estimates. Journal of Investing, 10(2), 29-35.

Doffou, A. (2003). Insider trading: A review of theory and empirical work. Journal of Accounting and Finance Research, 11(1), $1-17$.

Du, J., \& Wei, S. (2004). Does insider trading raise market volatility? The Economic Journal, 114(498), 916-942.

Frijns, B., Gilbert, A., \& Tourani-Rad, A. (2008). Insider trading, regulation, and the components of the bid-ask spread. Journal of Financial Research, 31(3), 225-246.

Frijns, B., Gilbert, A., \& Tourani-Rad, A. (2013). Do criminal sanctions deter insider trading? Financial Review, 48(2), $205-232$.

Garfinkel, J. A. (1997). New evidence on the effects of federal regulations on insider trading: The Insider Trading and Securities Fraud Enforcement Act (ITSFEA). Journal of Corporate Finance, 3(2), 89-111. 
Gaughan, P. A. (2011). Mergers, acquisitions, and corporate restructurings (5th ed.). New Jersey, NJ: John Wiley \& Sons, Inc..

Goergen, M., \& Renneboog, L. (2004). Shareholder wealth effects of European domestic and cross-border takeover bids. European Financial Management, 10(1), 9-45.

Jeng, L. A., Metrick, A., \& Zeckhauser, R. (2003). Estimating the returns to insider trading: A performance-evaluation perspective. Review of Economics and Statistics, 85(2), 453-471.

Keown, A. J., \& Pinkerton, J. M. (1981). Merger announcements and insider trading activity: An empirical investigation. Journal of Finance, 36(4), 855-869.

Khan, W. A., \& Lamba, A. S. (2001). The effectivenss of legal sanctions in curtailing insider trading: Evidence from exchange listings. Quarterly Journal of Business and Economics, 40(1), 3-15.

Marotto, T., \& Winterstein, P. (2007). Insider trading infects Brazil stocks as almost all deals leak. Bloomberg. Retrieved from http://www.bloomberg.com/apps/news?pid=newsarchive\&sid=alLE2VkNibWw

Meulbroek, L. K. (1992). An empirical analysis of illegal insider trading. Journal of Finance, 47(5), 1661-1699.

Meulbroek, L. K., \& Hart, C. (1997). The effect of illegal insider trading on takeover premia. European Finance Review, 1(1), 51-80.

Min, S. (2010). Can sanctions reduce insider trading? The experience of the USA in the 1980s. Asia-Pacific Journal of Financial Studies, 39(4), 417-444.

Morck, R., Shleifer, A., \& Vishny, R. W. (1990). Do managerial objectives drive bad acquisitions? Journal of Finance, 45(1), 31-48.

Mulherin, J. H., \& Boone, A. L. (2000). Comparing acquisitions and divestitures. Journal of Corporate Finance, 6(2), 117-139.

Prevoo, T., \& Weel, B. T. (2010). The effects of a change in market abuse regulation on abnormal returns and volumes: Evidence from the Amsterdam stock market. De Economist, 158(3), 237-293.

Rochman, R. R., \& Eid, W. (2006). Do insiders get abnormal returns? Event studies on the trades of insiders of the firms with differentiated corporate governance of the São Paulo Stock Exchange. SSRN Working Paper. Retrieved from http://ssrn.com/abstract=1435295

Rozeff, M. S. (1989). Reflections on insider trading. Financial Analysts Journal, 45(6), 12-15.

Schwert, G. W. (1996). Markup pricing in mergers and acquisitions. Journal of Financial Economics, 41(2), 153-192.

Seyhun, H. N. (1992). The effectiveness of the insider-trading sanctions. Journal of Law and Economics, 35(1), 149-182. 